\title{
Postsynaptic Inhibitors of Calcium/Calmodulin-Dependent Protein Kinase Type II Block Induction But Not Maintenance of Pairing- Induced Long-Term Potentiation
}

\author{
Nikolai Otmakhov, Leslie C. Griffith, and John E. Lisman \\ Volen Center for Complex Systems and Biology Department, Brandeis University, Waltham, Massachusetts 02254
}

\begin{abstract}
The role of postsynaptic kinases in the induction and maintenance of long-term potentiation (LTP) was studied in the CA1 region of the rat hippocampal slice. A peptide inhibitor for the catalytic domain of calcium/calmodulin-dependent protein kinase type II (CaM-kinase) was applied through a perfused patch pipette. The inhibitor completely blocked both the shortterm potentiation and LTP induced by a pairing protocol. This indicates that the kinase or kinases affected by the peptide are downstream from depolarization in the LTP cascade. The ability to block LTP required that measures be taken to interfere with degradation of the peptide kinase inhibitor by endogenous proteases; either addition of protease inhibitors or modifica-
\end{abstract}

tions of the peptide itself greatly enhanced the effectiveness of the peptide. Protease inhibitors by themselves or control peptide did not block LTP induction. To study the effect of kinase inhibitor on LTP maintenance, we induced LTP in one pathway. Subsequent introduction of the kinase inhibitor blocked the induction of LTP in a second pathway, but it did not affect maintenance of LTP in the first. The implications for the role of kinases in LTP maintenance are discussed.

Key words: long-term potentiation; calcium/calmodulindependent kinase; peptide inhibitors; hippocampal slices; whole-cell recording; intracellular perfusion; protease inhibitors; fluorescent imaging
Long-term potentiation (LTP) in the CA1 region of the hippocampus is the best-studied example of the activity-dependent synaptic modifications that may underlie learning and memory (Bliss and Collingridge, 1993; Malenka and Nicoll, 1993) There is now considerable biochemical, physiological, and genetic evidence for the involvement of protein kinases in LTP induction (Colley and Routtenberg, 1993; Suzuki, 1994; Roberson et al., 1996). Some experiments have shown specifically that blocking different postsynaptic kinases is sufficient to block LTP induction (Malenka et al., 1989; Malinow et al., 1989; O'Dell et al., 1991; Wang and Feng, 1992; Hvalby et al., 1994; Blitzer et al., 1995; Feng, 1995; Wang and Kelly, 1996). Furthermore, introduction of protein kinase $\mathrm{C}$ (C-kinase) or calcium/calmodulin-dependent protein kinase type II (CaM-kinase) (Hu et al., 1987; McGladeMcCulloh et al., 1993; Lledo et al., 1995) or their activators (Wang and Kelly, 1995) into the postsynaptic cell results in synaptic potentiation that may occlude tetanus-induced LTP (Wang and Kelly, 1995).

Although there is general agreement that postsynaptic kinases are involved in LTP induction, their exact role remains unclear. LTP is initiated by $\mathrm{Ca}^{2+}$ entry through the NMDA channels (Bliss and Collingridge, 1993), an entry that requires depolariza-

\footnotetext{
Received Feb. 12, 1997; revised May 5, 1997; accepted May 7, 1997.

This work was supported by National Institutes of Health Grant 2RO1NS27337. We gratefully acknowledge the support of the W. M. Keck Foundation. L.C.G. is an Alfred P. Sloan Fellow and a Klingenstein Fellow. We thank Dr. Roberto Malinow for providing a prototype of Axobasic program, Dr. Howard Schulman for the gift of CaMKII(273-302) peptide inhibitor, Dr. Angus Nairn for measuring the activity of some of the peptide inhibitors, Dr. Joseph Callaway for providing an upgrade of imaging acquisition software, Drs. Angus Nairn and Jean-Marc Fellous for reading this manuscript, Taylor Johnston for help in analyzing data, and Patricia McDonough for technical assistance in preparing this manuscript.

Nikolai Otmakhov also holds a position at the Institute of Theoretical and Experimental Biophysics, Russian Academy of Science, Pushchino, Russia.

Correspondence should be addressed to Dr. John E. Lisman at the above address

Copyright (C) 1997 Society for Neuroscience $0270-6474 / 97 / 175357-09 \$ 05.00 / 0$
}

tion (Mayer et al., 1984; Nowak et al., 1984). The depolarization may be provided by dendritic action potentials (Jaffe et al., 1992; Magee and Johnston, 1997) and the EPSP, both of which depend on voltage-dependent channels (Stuart and Sakmann, 1994, 1995; Andreasen and Lambert, 1995), which themselves may be regulated by phosphorylation (Levitan, 1994). It is possible therefore that inhibition of protein kinases interferes with LTP induction by lowering dendritic depolarization during LTP induction. In this paper we address this possibility by studying the effect of kinase inhibitors on the LTP induced by a pairing protocol in which postsynaptic depolarization is imposed.

It had been proposed that kinases also may maintain LTP (Lisman, 1985, 1994; Lou et al., 1986; Miller and Kennedy, 1986; Lisman and Goldring, 1988). Biochemical evidence shows that LTP induction produces a constitutive activation of both CaMkinase (Fukunaga et al., 1993, 1995; Ouyang et al., 1996; Barria et al., 1997) and C-kinase (Klann et al., 1991, 1992, 1993; Sacktor et al., 1993; Ramakers et al., 1995; Hrabetova and Sacktor, 1996). Experiments with bath application of nonspecific kinase inhibitors (Suzuki, 1994; Roberson et al., 1996) or inhibitors for C-kinase (Hrabetova and Sacktor, 1996) after LTP induction suggest that the maintenance can be blocked. Several investigations have attempted specifically to study the role of postsynaptic kinases in the maintenance, but the results are contradictory (Malinow et al., 1989; Huang et al., 1992; Malgaroli et al., 1992; Wang and Feng, 1992; Feng, 1995; Wang and Kelly, 1996). One technical complication is that cells were impaled only after LTP was induced, and so there was no direct evidence that it occurred in the recorded cells. We have investigated the effect of postsynaptic application of CaM-kinase inhibitor on LTP maintenance, using intracellular perfusion patch-clamp methodology. This makes it possible to introduce substances after LTP induction (Otmakhov and Lisman, 1995). 


\section{MATERIALS AND METHODS}

Slice preparation. Male Long-Evans rats (14-25 d old) were anesthetized by isoflurane and decapitated. The brain was removed quickly and submerged in ice-cold artificial cerebrospinal fluid (ACSF; see composition below). Transverse hippocampal slices (400 $\mu \mathrm{m}$ thick) were prepared at $0-4^{\circ} \mathrm{C}$ with a vibratome (Vibratome 1000 , Ted Pella, Redding, CA). The CA3 region of each slice was isolated surgically from CA1. Before recording, slices were kept at least $2 \mathrm{hr}$ on cell culture inserts (Falcon, $8 \mu \mathrm{m}$ pore diameter) covered by a thin layer of ACSF and surrounded by a humidified $95 \% \mathrm{O}_{2} / 5 \% \mathrm{CO}_{2}$ atmosphere. For recording, slices were transferred to a submerged-type recording chamber with continuous flow $(1.5 \mathrm{ml} / \mathrm{min})$ of ACSF. The ACSF contained (in $\mathrm{mM}$ ): $\mathrm{NaCl} 124, \mathrm{NaHCO}_{3} 26, \mathrm{NaH}_{2} \mathrm{PO}_{4} 1.25, \mathrm{KCl} 2.5, \mathrm{CaCl}_{2} 4, \mathrm{MgSO}_{4} 4$, D-glucose 20, and picrotoxin 0.1. ASCF was saturated with $95 \% \mathrm{O}_{2}$ $5 \% \mathrm{CO}_{2}, \mathrm{pH} 7.4$, and warmed $\left(22-25^{\circ} \mathrm{C}\right)$.

Electrical recording and stimulation. Voltage-clamp whole-cell recording was performed with an Axopatch-1D amplifier (Axon Instruments, Foster City, CA) with low-pass filter set at $1 \mathrm{kHz}$. The patch pipettes had resistances of 2.5-3.5 M $\Omega$ when filled with pipette solution. The pipette solution contained (in mM): Cs-methanesulfonate 120, CsCl 20, HEPES 10, MgATP 4, $\mathrm{Na}_{3}$ GTP 0.3, EGTA 0.2, and phosphocreatine 10, pH 7.3, with osmolarity at $300 \mathrm{mOsm}$. Patching was performed under visual control, using infrared oblique illumination and a CCD TV camera (see also Optical Recording below). Recordings were made from cell bodies in the CA1 pyramidal layer located $40-100 \mu \mathrm{m}$ beneath the slice surface. Cell currents were measured in voltage-clamp mode. Series and input resistances were monitored every $6 \mathrm{sec}$ by measuring the peak and steady-state currents in response to $2 \mathrm{mV}, 38 \mathrm{msec}$ depolarizing steps. For monitoring the stability of the slice responsiveness, field potentials were recorded simultaneously. These were recorded with a glass pipette filled with ACSF (300 $\mathrm{k} \Omega$ resistance) positioned near the dendritic region of the recorded cell at $\sim 100 \mu \mathrm{m}$ from the cell body. An Axoclamp-2A (Axon Instruments) and a custom (1000×) amplifier $(0.5$ $\mathrm{Hz}-1.0 \mathrm{kHz}$ ) were used for the amplification of field potentials. Both intracellular and extracellular recorded signals were digitized at 5-10 $\mathrm{kHz}$, stored, and analyzed by custom software written in Axobasic 3.1. For stimulation of two pathways of Schaffer collaterals, two glass pipettes filled with ACSF (300 $\mathrm{k} \Omega$ resistance) were positioned in the dendritic region $\sim 70$ and $150 \mu \mathrm{m}$ from the cell body layer and $\sim 50 \mu \mathrm{m}$ from the dendritic tree of the recorded cell (see Fig. 1A). Single-shock stimuli (2-50 $\mu \mathrm{A}, 150 \mu \mathrm{sec}$ duration square pulse) were delivered every $6 \mathrm{sec}$ through current output isolation units (Isostim-A320, World Precision Instruments, Sarasota, FL).

LTP induction by pairing. To induce LTP, we transiently depolarized a cell from -65 to $0 \mathrm{mV}$, and we delivered 200 stimuli to one of the synaptic inputs at $1.4 \mathrm{~Hz}$. The depolarization or increased stimulus frequency alone did not produce any significant lasting changes in synaptic response. LTP was blocked completely if ACSF contained $100 \mu \mathrm{M}$ D,L-APV $(n=3)$ or if 20 mM BAPTA was included in the pipette solution $(n=7)$. It has been reported that the ability to induce LTP or short-term potentiation (STP) "washes out" during the first 20-30 min of whole-cell recording (Malinow and Tsien, 1990; Kullmann et al., 1992) and that inclusion of an ATP-regenerating internal solution may prolong this period (Kullmann et al., 1992). In our experiments we needed to have reliable induction of LTP after periods of intracellular perfusion long enough to ensure that a high concentration of kinase inhibitor had reached distal dendritic regions. Our preliminary experiments showed that the amplitude and reliability of LTP induction decrease with time. However, if pairing was done within $20 \mathrm{~min}$ of the start of whole-cell recording, LTP induction was reliable (in $95 \%$ cases with average amplitude $\sim 300 \%$; see Results).

Optical recording. A custom electrophysiology setup, based on a Nikon fluorescent microscope $(40 \times / 0.75$ numerical aperture water immersion objective, Achroplan, Zeiss, Oberkochen, Germany), was used for visually controlled patching and fluorescent signal imaging (Malinow et al., 1994). A cooled CCD camera (CH250/A, Photometrics), filter cube B-2H (Chroma Tech), and software written by Dr. Nahama Lasser-Ross (Lasser-Ross et al., 1991) and modified by Dr. Joseph Callaway (University of Tennessee, Memphis, TN) were used for taking single pictures from selected dendritic regions.

Intracellular perfusion. A pipette holder with a side port allowing entry of PE10 polyethylene tubing (Intramedic, Clay Adams, Sparks, MD) was used for controlled changes of intrapipette solutions. The polyethylene tubing was mated (epoxy seal) to a quartz capillary tube (Adams \& List, Westbury, NY) pulled to a tip diameter $\sim 15 \mu \mathrm{m}$ in diameter. The tip was positioned $80-200 \mu \mathrm{m}$ from the mouth of the patch pipette. Internal solution was pushed slowly $(0.4 \mu \mathrm{l} / \mathrm{min})$ through the PE10 tubing, using a $10 \mu \mathrm{l}$ syringe filled with mineral oil and driven by a stepping motor. A fluorescent dye, carboxyfluorescein $(25 \mu \mathrm{M})$, was added to the pipette solution in experiments designed to monitor perfusion efficiency (see Fig. 1). Our measurements indicate that solution ejected from the capillary reached the pipette mouth within $10-30 \mathrm{sec}$ and that steady-state concentrations were achieved within 3-4 min. The ejection of 3-4 $\mu$ l of solution was sufficient to maintain the tip concentration at stable values for $>100$ min even after the flow through the capillary was stopped. In several experiments rhodamine-labeled peptide inhibitor (see below) was perfused to monitor peptide delivery into a cell. We found that care had to be taken to keep light exposure minimal to prevent dye bleaching and photodynamic damage to the cell.

Formation of a gigaohm seal was difficult with $2 \mathrm{~mm}$ of the CaMKII(AC3) peptide in the patch pipette. Therefore, in the experiments in which the effect of inhibitors on LTP induction was tested, the peptide perfusion was started after the seal was formed and before the cell membrane was ruptured (see Figs. 2, 3, 5). In the experiments in which just standard control pipette solution was used, no perfusion was performed.

Enzyme assays. CaM-kinase activity was assayed with autocamtide-3 (AC3) as a substrate. Reactions were performed in a final volume of 50 $\mu \mathrm{l}$ at $30^{\circ} \mathrm{C}$ for $1 \mathrm{~min}$. Reaction solutions contained $50 \mathrm{~mm}$ PIPES, pH 7.0, $15 \mathrm{mM} \mathrm{MgCl} 2,1 \mathrm{mg} / \mathrm{ml}$ bovine serum albumin, $12.8 \mathrm{ng}$ of Drosophila CaM-kinase R3 isoform purified from transfected COS cells as described (GuptaRoy and Griffith, 1996), $13.8 \mu \mathrm{M}$ AC3, $10 \mu \mathrm{g} / \mathrm{ml}$ bovine calmodulin (Boehringer Mannheim, Indianapolis, IN), $1 \mathrm{mM} \mathrm{CaCl}_{2}$, and $50 \mu \mathrm{M}$ $\left(\gamma^{-}{ }^{32} \mathrm{P}\right)$ ATP, specific activity $1 \mathrm{Ci} / \mathrm{mmol}$. Unstimulated activity was determined by substituting $0.5 \mathrm{~mm}$ EGTA for $\mathrm{CaCl}_{2}$ and calmodulin. Reactions were stopped by the addition of $50 \mu \mathrm{l}$ of $10 \%$ trichloroacetic acid. Samples were microf uged, and $25 \mu l$ of supernatant was applied to a strip of phosphocellulose paper (Whatman, Maidstone, UK) that was washed in running water for $15 \mathrm{~min}$. Phosphate incorporation was determined by measuring Cerenkov radiation in a Beckman LS6500 scintillation counter.

Characterization of peptides. Three specific inhibitors of CaM-kinase were used: AC3-derived peptide inhibitor (KKALHRQEAVDAL) (Braun and Schulman, 1995) (synthesized at the University of Michigan Protein and Carboxyhydrate Structure Facility, Ann Arbor, MI), CaMkinase (AC3)-protected peptide inhibitor (Ac-KKALHRQEAVDAL$\mathrm{NH}_{2}$ ) (synthesized at QCB, Hopkinton, MA), and pseudosubstrate peptide inhibitor corresponding to residues $273-302$ of the rat $\alpha$-CaMkinase HRSTVASCMHRQETVDCLKKFNARRKLKGA (Malinow et al., 1989) (a gift of Dr. H. Schulman, Stanford University, Stanford, CA). A rhodamine-conjugated AC3 peptide also was used in some experiments (University of Michigan Protein and Carboxyhydrate Structure Facility). These inhibitors act on the catalytic domain of CaMkinase (Ocorr and Schulman, 1991; Ishida and Fujisawa, 1995). The $\mathrm{IC}_{50}$ values for CaMKII(273-302) and CaMKII(AC3) inhibitory peptides are $1 \mu \mathrm{M}$ (Malinow et al., 1989) and $3 \mu \mathrm{M}$ (Braun and Schulman, 1995) (assay performed by Dr. Angus Nairn, Rockefeller University, New York, NY), respectively. These inhibitors also can affect PKC but at much higher concentrations $\left(\mathrm{IC}_{50}>200\right.$ and $\sim 500 \mu \mathrm{M}$, respectively) (Malinow et al., 1989; Braun and Schulman, 1995) (but see Hvalby et al., 1994). For the CaMKII(AC3)-protected peptide inhibitor, $\mathrm{IC}_{50}$ was found to be $\sim 5 \mu \mathrm{M}$ (assay performed by Dr. Angus Nairn). A peptide with the reversed amino acid sequence of the AC3 inhibitor was synthesized as a control peptide (University of Michigan Protein and Carboxyhydrate Structure Facility). This peptide has no inhibitory activity toward CaM-kinase even up to $1 \mathrm{~mm}$ final concentration. The CaMKII(AC3) inhibitor was tested to determine whether its efficiency depends on ATP concentration. There was no effect on inhibitory activity in vitro by ATP at concentrations between $20 \mu \mathrm{M}$ and $2 \mathrm{~mm}$. To determine whether the peptide was degraded during handling, we assayed its inhibitory activity in vitro after it was exposed to experimental conditions. Storage of the peptide in the patch pipette and in the polyethylene tubing of the perfusion apparatus for $3 \mathrm{hr}$ at room temperature was found to have no effect on its activity.

Drug preparation for electrophysiology. Stock solutions of peptides $(20$ $\mathrm{mm}$ in distilled water) were divided into $2 \mu \mathrm{l}$ aliquots and stored at $-70^{\circ} \mathrm{C}$. Each aliquot was thawed only once and used for the experiments of $1 \mathrm{~d}$. The final concentration $(1$ or $2 \mathrm{~mm})$ of a peptide-containing pipette solution was prepared by diluting $2 \mu \mathrm{l}$ of stock solution in a special pipette solution $10 \%$ more concentrated than the standard (see above). Protease inhibitors (Boehringer Mannheim) were prepared in 


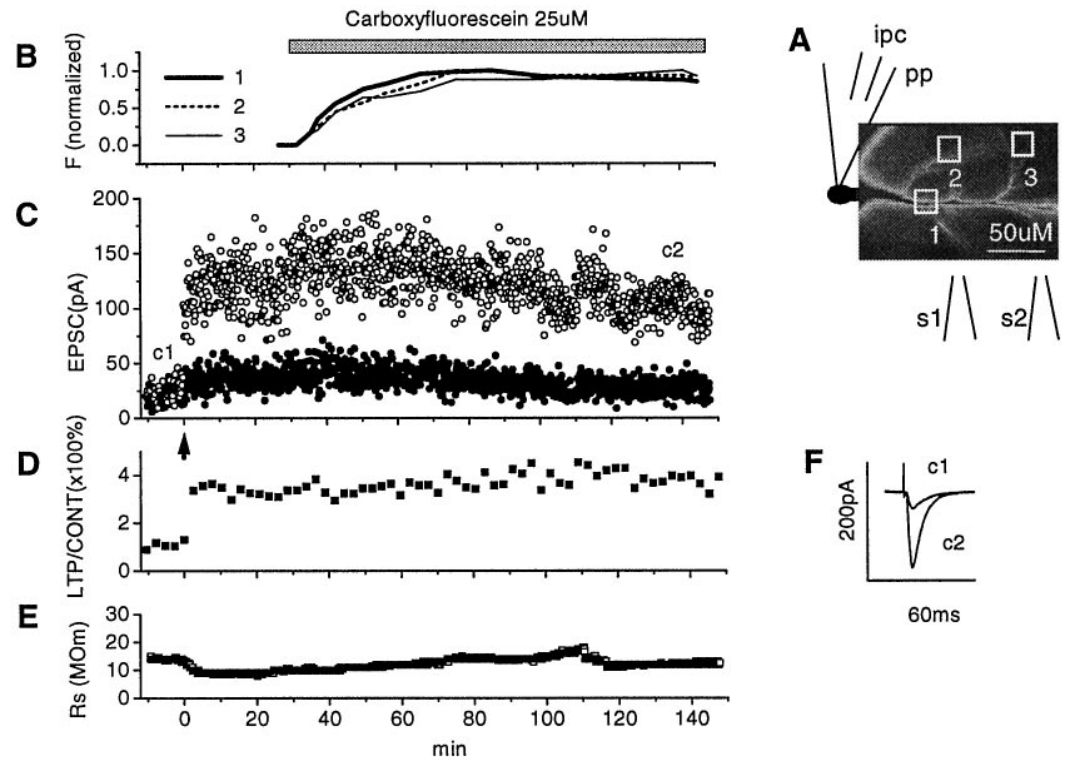

Figure 1. Diffusion of dye into dendrites after the introduction of dye into the patch pipette. $A$, Picture of the dendritic region of a pyramidal cell after it was filled with fluorescent dye (carboxyfluorescein, $25 \mu \mathrm{M}$ ) in the patch pipette ( $p p$; soma diagrammed at left); an intrapipette capillary was used (ipc). Relative positioning of two stimulation electrodes ( $s 1$ and $s 2$ ) is indicated. $B$, Time course of the dye fluorescence measured at three different distances from the soma of the neuron (see numbered regions in $A$ ). $C$, Magnitude of synaptic responses of the cell as a function of time during the experiment. Thirty minutes after the induction of LTP in one pathway (open circles), the dye was perfused into the patch pipette (see $A, B$ ). This perfusion did not significantly affect either the LTP or the control ( filled circle) pathways (see also D). D, Ratio of the amplitudes of LTP versus the control synaptic responses. Each point is the ratio of the average of 20 responses. $E$, Series resistance for this recording. $F$, Averages of 20 consecutive synaptic responses before (c1) and 140 min after (c2) LTP induction. two stock solutions. The first solution combined leupeptin and bestatin (10 $\mathrm{mm}$ each in distilled water, $5 \mu$ l aliquots). The second solution contained pepstatin A ( $25 \mathrm{~mm}$ in dimethylsulfoxide, $2 \mu$ l aliquots). For each experiment one aliquot of each solution was thawed and diluted in pipette solution to give a final concentration of $0.1 \mathrm{~mm}$. BAPTA (Cs salt) was prepared fresh for each experiment at a final concentration of $10 \mathrm{~mm}$. D,L-APV (Research Biochemicals, Natick, MA) was added to the bath ACSF at final concentration of $100 \mu \mathrm{M}$. pH of the final peptide solution was adjusted with HEPES $(120 \mathrm{~mm}, \mathrm{pH} \sim 9.0)$. Osmolarity was measured routinely (VAPRO 5520, Wescor, Logan, UT) and adjusted, if necessary, with distilled water.

Statistical analysis. The amplitude of synaptic response was calculated as the difference between the averages of data points in a window before the stimulus and in a window around the peak of synaptic response. In figures describing individual experiments, each data point represents an individual measurement. In figures that summarize the average of experiments, individual values for each experiment were normalized first relative to the baseline period before pairing and then averaged over $2 \mathrm{~min}$. The resulting values were used to calculate the mean $\pm S E M$ for each 2 min period. The magnitude of LTP was calculated as a percentage of LTP pathway responses averaged for 6 min at the end of the period shown on the graphs (if not specified otherwise) relative to responses for the period of baseline recording before LTP induction. A two-independent-population $t$ test was used for calculation of statistical significance of differences. All calculations and plots were done by the spread sheet program Origin 4.1 (MicroCal Software, Northampton, MA).

\section{RESULTS}

To estimate the time that it takes for substances applied through the patch pipette to fill the dendrites, we monitored this process with the fluorescent dye carboxyfluorescein $(25 \mu \mathrm{M})$. Figure 1 shows an experiment in which a whole-cell recording was obtained with our standard nonfluorescent pipette solution. After establishing a stable baseline of synaptic transmission, we induced LTP by pairing (see Materials and Methods). 35 min later, dye was perfused into the patch pipette. Images of the fluorescence were taken at 5-20 min intervals. Figure $1 A$ shows the regions of the dendrite that were analyzed. Figure $1 B$ demonstrates how fluorescence intensity changed over time in these regions. In recordings in which the series resistance was relatively high (10-20 M $\Omega$, Fig. $1 E$ ), it took 20-40 min for the dye to reach $\sim 90 \%$ of maximal fluorescence intensity in the dendrites. The proximal, thick dendritic shaft was filled faster than thin distal branches. This time course is in rough agreement with other measurements of the diff usion of dyes into dendrites (Rexhausen,
1992; Helmchen et al., 1996). The perfusion process itself did not affect the synaptic responses in either the potentiated pathway or the control pathway (Fig. $1 C$ ), and the level of LTP, expressed as the ratio of LTP versus control synaptic responses, was stable during the recording (Fig. 1D). In other experiments in which the series resistance was lower (10 $\mathrm{M} \Omega$ ), the time required to fill the dendrites was almost twice as fast. Experiments using a fluorescently tagged peptide showed that fluorescence appears in the dendrites with a time course similar to that of carboxyfluorescein; however, because of the possibility of proteolysis (see below), we cannot be certain that the dye remained bound to the complete peptide. On the basis of the molecular weight difference of carboxyfluorescein (MW 300) and the CaMKII(AC3) inhibitory peptide used below (MW 1500) and using equations for free diffusion (Cantor and Schimmel, 1980), we estimate that the peptide should diffuse $\sim 1.7$ times slower than the dye.

It has been reported that the postsynaptic application of a pseudosubstrate peptide inhibitor of CaM-kinase blocks the development of tetanus-induced LTP (Malinow et al., 1989; Hvalby et al., 1994; Feng, 1995). We conducted experiments to determine whether similar inhibitors could block the induction of LTP during a pairing protocol in which the membrane was voltageclamped to $0 \mathrm{mV}$ and synapses were stimulated at $1.4 \mathrm{~Hz}$ for 200 stimuli. Pairing was performed after $20 \mathrm{~min}$ of baseline recording in the whole-cell configuration. To our surprise, LTP was not blocked by the kinase inhibitor (306 $\pm 23 \%, n=3$; Fig. $2 A)$ and was not significantly different from LTP induced with control solution $(250 \pm 13 \%, n=4, p>0.5$; Fig. $2 B)$.

One explanation of the ineffectiveness of the kinase inhibitor might be that it was degraded by intracellular proteases. Indeed, it has been reported that a peptide kinase inhibitor injected into living cell can be proteolysed within 20-30 min (Fernandez et al., 1991). If such proteolysis occurs in our experiments, our peptide inhibitor would be destroyed, for the most part, by the time it diffused into the dendrites. To test this possibility, a protease inhibitor cocktail (leupeptin + bestatin + pepstatin A, each at 0.1 $\mathrm{mm}$ ) was added to the pipette solution. With this addition the same concentration (2 $\mathrm{mM})$ of kinase inhibitor completely blocked LTP induction $(100 \pm 7 \%, n=18$; Fig. $3 A, C)$. In control experiments in which $2 \mathrm{mM}$ of inactive $\mathrm{AC} 3$ peptide was perfused, 
Figure 2. CaMKII(AC3) inhibitor peptide does not affect LTP if applied postsynaptically without protease inhibitors. Open symbols indicate the pathway where the pairing procedure was applied at time 0 (arrow). Filled symbols indicate the control pathway. LTP was induced after $20 \mathrm{~min}$ of whole-cell recording. When protease inhibitors were not included with 2 mM of CaMKII(AC3) inhibitor peptide $(A)$, the level of LTP was not affected in comparison to the level of LTP induced with the control pipette solution $(B)$.
Figure 3. Postsynaptic application of CaMKII(AC3) inhibitor peptide completely blocked induction of LTP, provided that protease inhibitors were used. Open symbols indicate the pathway where the pairing procedure was applied at time 0 (arrow). Filled symbols indicate the control pathway. LTP was induced after $20 \mathrm{~min}$ of whole-cell recording. $A$ and $B$ show individual experiments, and $C-F$ show pooled data. In all experiments a protease inhibitor cocktail was included in the pipette solution. $A, C$, CaMKII(AC3) (2 mM) inhibitor peptide completely blocked both LTP and STP; when $1 \mathrm{mM}$ of the kinase inhibitor was applied $(B, D)$, LTP still could be induced in many cases, but its magnitude was decreased significantly, as compared with controls in which the pipette solution contained protease inhibitors but no kinase inhibitor $(E)$ or 1 or $2 \mathrm{~mm}$ of the inactive CaMKII(AC3) control peptide $(F)$. Insets in $A, B$, Averages of 20 consecutive traces of EPSCs taken in the periods indicated in the corresponding panels. Calibration: $150 \mathrm{pA}, 100 \mathrm{msec}$ for $A ; 500 \mathrm{pA}, 100$ msec for $B$.
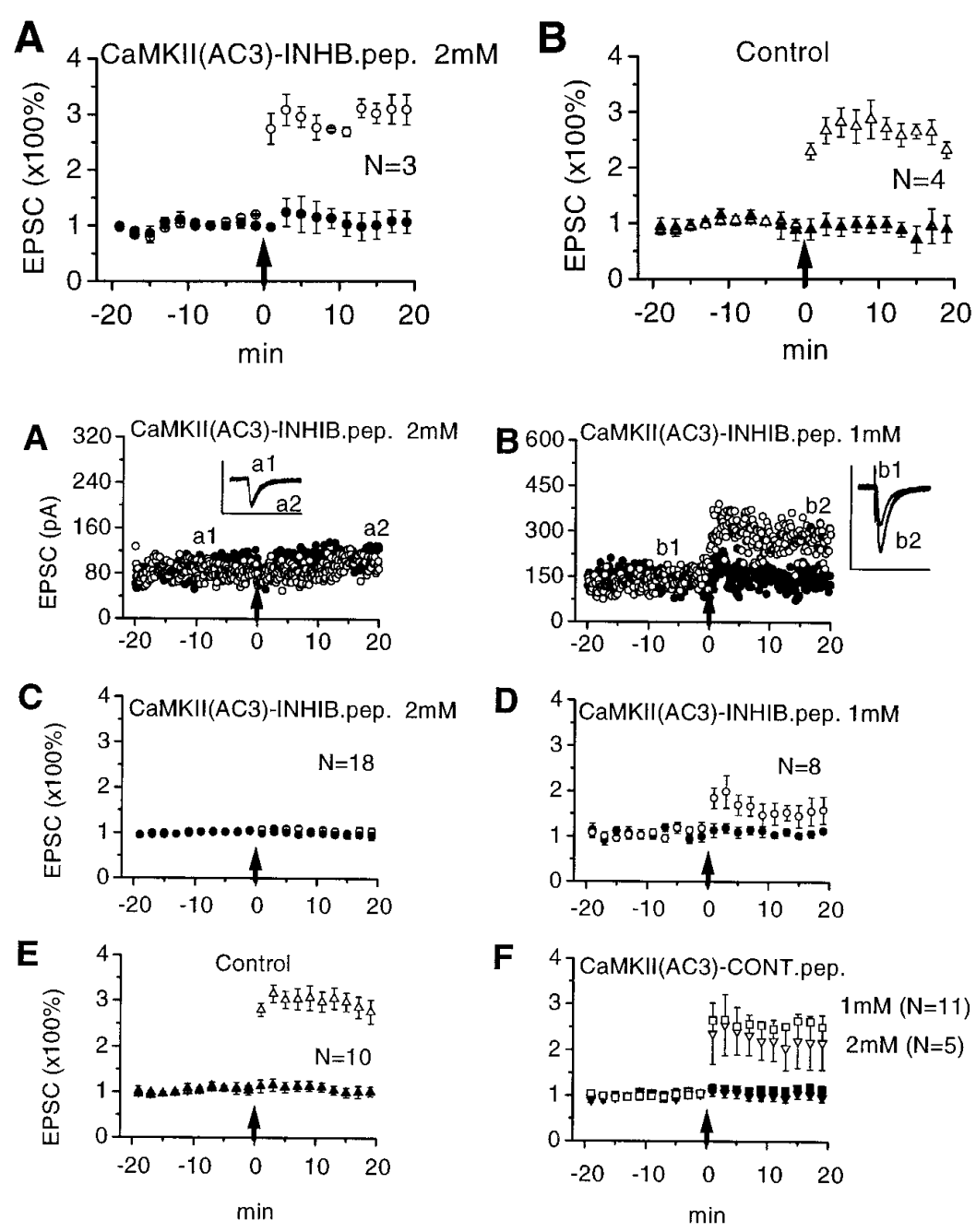

LTP level was large $(218 \pm 59 \%, n=5, p<0.001$; Fig. $3 F)$. In some previous work a STP remained after kinase inhibition (for review, see Bliss and Collingridge, 1993; Roberson et al., 1996). In contrast, we found that all phases of LTP were blocked (Fig. $3 A, C)$. Lower concentrations (1 $\mathrm{mm}$ ) of kinase inhibitor reduced LTP, but the block was incomplete $(153 \pm 26 \%, n=8$; Fig. $3 B, D)$ in comparison to LTP induced with $1 \mathrm{mM}$ of control peptide in pipette $(254 \pm 18 \%, n=11, p<0.05$; Fig. $3 F)$. Importantly, LTP was not affected significantly by the protease inhibitor cocktail alone $(287 \pm 20 \%, n=10, p>0.05$; Fig. $3 E)$ or by protease inhibitor cocktail plus $1 \mathrm{~mm}$ or $2 \mathrm{~mm}$ of inactive CaMKII(AC3) control peptide ( $p>0.05$ for both; Fig. $3 F)$ if compared with the level of LTP without protease inhibitors (Fig. 2B). Thus neither peptide per se nor the protease inhibitors can account for the complete block of LTP induction by kinase inhibitor. We conclude that induction of LTP by a pairing protocol requires postsynaptic kinase activity.

Having established that a sufficient amount of kinase inhibitor enters the dendrites in 20 min to block LTP induction totally, we were in a position to determine whether the introduction of kinase inhibitor after LTP induction could affect the maintenance of LTP. Figure $4 A$ shows a representative experiment in which AC3 peptide was perfused 15 min after induction of LTP. Figure 4, $B$ and $C$, demonstrates summary data from two series of experiments in which two different peptide inhibitors of CaMkinase were perfused into a cell starting $15 \mathrm{~min}$ after LTP induction (Fig. 4B, AC3 inhibitor; Fig. 4C, CaMKII(273-302); both, $2 \mathrm{~mm}$ with protease inhibitors). LTP maintenance was monitored over the next hour. Neither inhibitory peptide produced any obvious change in LTP maintenance when compared with the control without addition of kinase inhibitor (Fig. 4D). We quantified summary data by comparing the decay of potentiated synaptic response between a time just after LTP induction but before application of kinase inhibitor (at 9-15 $\mathrm{min}$ ) and at a time 59-65 min after application of kinase inhibitor. With kinase inhibitors the changes were small [down $7 \pm 8 \%$ (Fig. $4 B$ ) or up $6 \pm 5 \%$ (Fig. $4 C$ )] and not significantly different from in the control [down $5 \pm 7 \%$ (Fig. $4 D$ ), $p>0.05$ for both peptides]. We conclude that maintenance was not affected by the kinase inhibitors.

There is a possibility, however, that a higher concentration of the inhibitor is required to affect maintenance of LTP than to block LTP induction. Furthermore, there are various proteases that might not be affected by our protease inhibitor cocktail. Therefore, the peptide inhibitor could be proteolysed partly, even in the presence of the protease inhibitor cocktail. As another way of reducing proteolysis, we modified CaMKII(AC3) inhibitor peptide by adding acetyl and amide groups to the ends of the peptide (Ac-KKALHRQEAVDAL- $\mathrm{NH}_{2}$ ). This modification should make the peptide more resistant to some forms of protease (Bond and Butler, 1987; Ciechanover and Schwartz, 1989; Fernandez et al., 1991). In vitro kinase assays indicated that this 

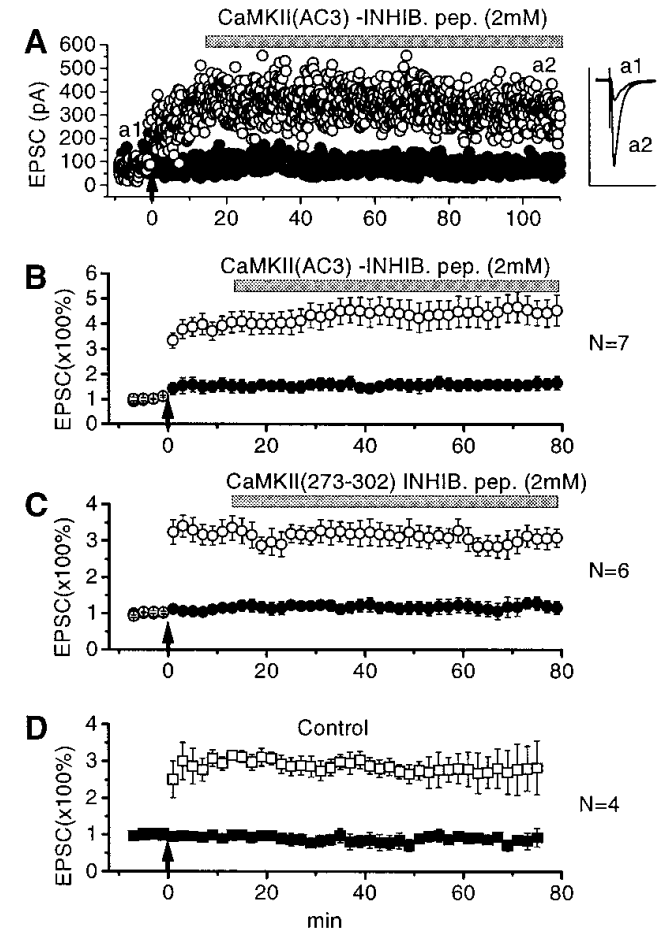

Figure 4. Postsynaptic application of CaMKII inhibitor peptides after LTP induction did not affect the maintenance of LTP. Shown are a representative experiment $(A)$ and pooled data $(B)$ of seven similar experiments when CaMKII(AC3) inhibitor peptide $(2 \mathrm{mM})$ was perfused during the period marked by the horizontal bar. $C$, Pooled data of six experiments when CaMKII(273-302) inhibitor peptide (2 mM) was perfused. $A-C$, Protease inhibitors were included in the patch pipette during the entire experiment. $D$, Pooled data of four control experiments. Open symbols are for the pathway in which LTP was induced by the pairing protocol (at arrow); filled symbols are for the control pathway. Insets in $A$, Averages of 20 consecutive traces of EPSCs taken in the periods indicated in $A$. Calibration, $500 \mathrm{pA}, 100 \mathrm{msec}$.
A

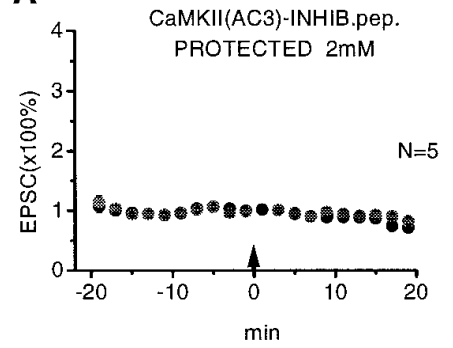

B

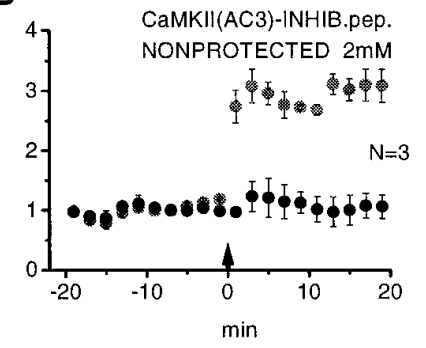

Figure 5. Modified CaMKII(AC3) inhibitor (resistant to protease degradation) completely blocked induction of LTP even when protease inhibitors were not included in the patch pipette solution. $A$, Protected peptide (see Materials and Methods) completely blocked LTP induction 20 min after the start of whole-cell recording. $B$, Large LTP was produced when unprotected peptide was applied. Gray symbols are for the pathway in which LTP was induced by pairing at the arrow. Filled symbols are for the control pathway.

protection left the inhibitory activity of the peptide intact (see Materials and Methods). Introduction of $2 \mathrm{~mm}$ of the protected peptide without protease inhibitors completely blocked induction of LTP and STP $(83 \pm 4 \%, n=5$; Fig. $5 A)$. Because the nonprotected CaMKII(AC3) inhibitor did not block LTP without addition of protease inhibitors $(306 \pm 23 \%, n=3$; Fig. $5 B)$, we conclude that the protective modifications were effective.
To protect maximally the peptide inhibitor from degradation, we did experiments in which protected CaMKII(AC3) peptide inhibitor was perfused together with the protease inhibitor cocktail. The experiment was designed with two synaptic input pathways so that we could induce LTP in one pathway, apply inhibitor, and then prove, using the second pathway, that the peptide had arrived in the dendrites in sufficient concentration to block LTP induction. This experiment is shown in Figure 6. After 6 min of baseline recording, LTP was induced in one pathway. Two minutes later, either CaMKII(AC3)-protected peptide inhibitor or control peptide ( $2 \mathrm{~mm}$ each) was perfused into the pipette. Ten minutes later, a pairing procedure was applied to the second pathway. The LTP induction in the second pathway was blocked completely in experiments in which peptide inhibitor was perfused $(92 \pm 14 \%, n=8$; Fig. $6 A, D)$ but was preserved in experiments in which control peptide was perfused $(338 \pm 74 \%$, $n=3, p<0.001$; Fig. 6B,D). We now can ask what effect this peptide had on the maintenance of LTP in the first pathway. The interpretation is complicated by the fact that the first pathway underwent a small heterosynaptic depotentiation when LTP was induced in pathway 2. However, this also occurred in cells perfused with control peptide (Fig. 6B). When the decay of the first pathway is compared for the active $(-34 \pm 5 \%)$ and control $(-23 \pm 20 \%$ ) peptide (Fig. $6 C$ ), it can be seen that there is little difference $(p>0.05)$. In the design of this experiment we systematically placed the stimulating electrode for the second pathway more distally than for the first (Fig. $1 A$ ). This ensured that if peptide reached the region of the second pathway, it certainly must have reached the region of the first.

To avoid the complications of heterosynaptic depotentiation in Figure 6, we did a second set of experiments in which LTP was not induced in the second pathway. Figure 7 shows experiments in which $2 \mathrm{~mm}$ CaMKII(AC3)-protected peptide inhibitor (with protease inhibitor cocktail) was introduced 2 min after LTP induction, and its effects were monitored over the next hour. Figure $7 A$ demonstrates the results of a representative experiment. Simultaneous measurements of the series resistance, input resistance, and field EPSPs demonstrate the stability of the recording in the slice. Figure $7 B$ shows pooled data from several similar experiments in which the inhibitor peptide or inactive control peptide (both with protease inhibitor cocktail) was perfused. We observed no significant differences between active peptide (Fig. 7B1) and inactive peptide (Fig. 7B2), as can be seen by the superposition in Figure $7 B 3$. The decay of the LTP measured between 3-9 $\mathrm{min}$ and 53-59 min was $7 \pm 11 \%$ with active kinase inhibitor and $14 \pm 13 \%$ with control peptide. These differences were not statistically significant $(p>0.5)$.

\section{DISCUSSION}

We show here that introduction of CaMKII(AC3) peptide inhibitor into the postsynaptic cell completely blocks the induction of LTP produced by pairing but does not affect LTP maintenance. All previous studies on the effect of kinase inhibitors on LTP induction used a tetanus to induce LTP. It was possible therefore that kinase inhibitors affected voltage-dependent channels, thereby preventing the depolarization necessary to strongly activate the NMDA channels. The use of a pairing protocol in our experiments eliminates this possibility. Pairing, when used in conjunction with a Cs-based internal solution that blocks $\mathrm{K}^{+}$ channels, provides controlled depolarization of the dendritic membrane. Under these conditions a clear reversal of the synaptic current is observed near $0 \mathrm{mV}$, the expected reversal voltage. 
Figure 6. Ten minutes of intracellular application of protected CaMKII(AC3) inhibitor peptide completely blocked induction but did not affect early maintenance of LTP. CaMKII(AC3) peptide inhibitor was modified to resist protease degradation. Protease inhibitors also were included in the patch pipette. Six minutes after the start of whole-cell recording, LTP was induced in one pathway (open or gray symbols). Two minutes later, kinase inhibitor or inactive control CaMKII(AC3) peptide was applied (horizontal bars). Ten minutes later, the ability of the kinase inhibitor to inhibit LTP induction in the second pathway ( filled symbols) was tested. $A$, Protected kinase inhibitor. $B$, Control peptide. $C$, Superposition of the data from the first pathways in $A$ and $B$. $D$, Superposition of the data from the second pathways in $A$ and $B$. Arrows indicate the time when the LTP induction protocol was applied.
A
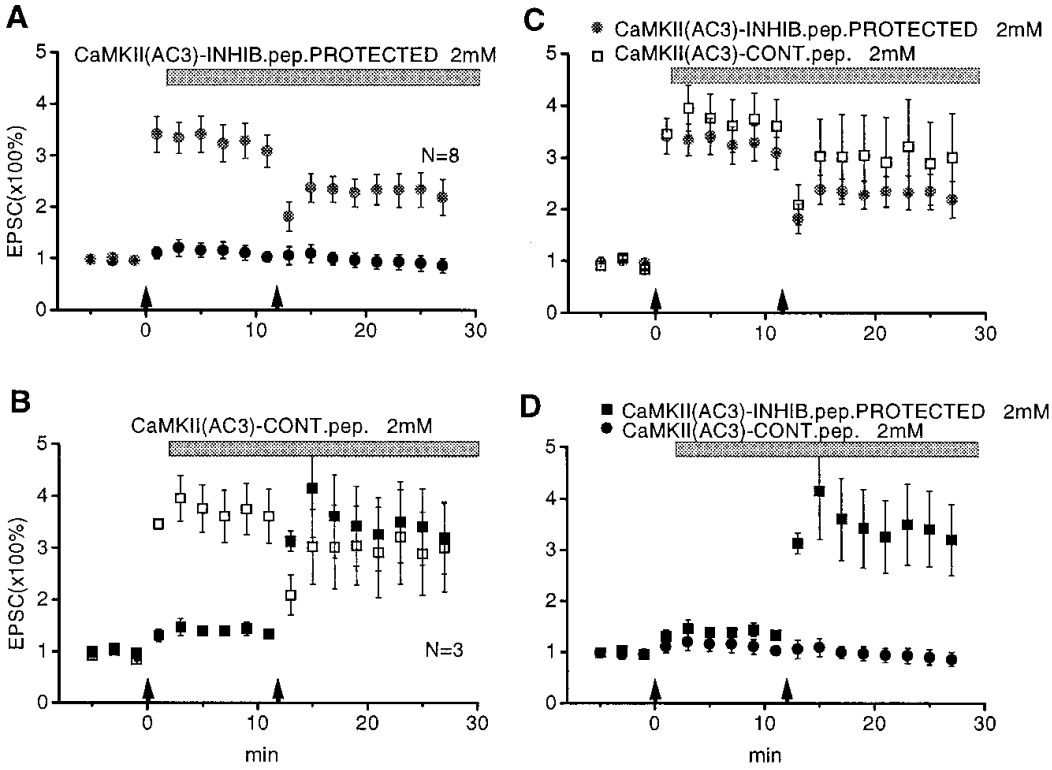

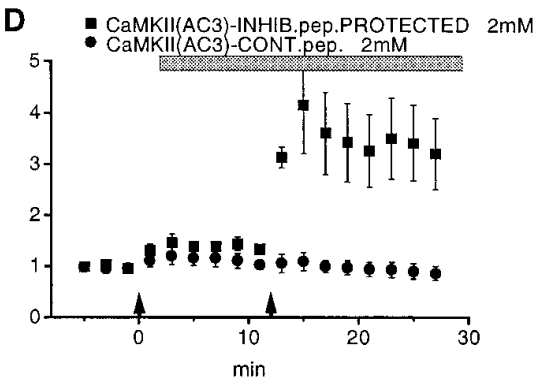

This indicates that, under the conditions of our experiments, the voltage control is sufficiently good to depolarize substantially the dendritic membrane (Hestrin et al., 1990).

The block of LTP by kinase inhibitors was complete and occurred for all phases of potentiation. Previous work had given some indication that STP might not be blocked by kinase inhibitors (for review, see Bliss and Collingridge, 1993; Roberson et al., 1996). This gave rise to the idea that STP involved a mechanism that was mechanistically separate from LTP. More recent work, however, suggests that STP is induced selectively whenever the induction protocol is weakened and that LTP and STP are affected equally by kinase inhibitors, suggesting that STP reflects an impaired form of LTP (Hanse and Gustafsson, 1994). Our results indicate involvement of the kinases in both forms of potentiation, a result also reported by Hvalby et al. (1994) when high concentrations of peptide inhibitors for CaM-kinase or $\mathrm{C}$-kinase were used. The simplest interpretation of previous work in which STP was not blocked is that the kinase inhibition was only partial.

In most previous studies on the effects of kinase inhibitors on LTP, inhibitors were delivered by leakage from a microelectrode. Because access resistance is a critical factor controlling the entry of substance from the electrode into the cytoplasm (Pusch and Neher, 1988; our unpublished observations) the lower access resistance of patch pipettes should allow more quantitative control of the cytoplasmic concentration of applied substances. However, even with patch methods the problem of peptide proteolysis introduces considerable uncertainty regarding the actual concentration of functional peptide inhibitor in the dendrites. The steps we have taken to reduce proteolysis clearly enhance the effectiveness of the peptide at blocking LTP, but we have no measure of whether proteolysis has been blocked completely by these procedures or merely reduced. Because we cannot estimate the concentration of inhibitor in the dendrites, no strong conclusions can be reached concerning the identity of the kinases involved in LTP induction. In vitro work indicates that the class of peptide inhibitor we have used is $>200$ times more selective against CaMkinase II than against C-kinase (Malinow et al., 1989; Ocorr and Schulman, 1991; Braun and Schulman, 1995; Ishida and Fujisawa, 1995) (but see Hvalby et al., 1994). Because of the high concen- tration of peptide we have used and because of the uncertainties regarding concentrations, we cannot eliminate the possibility that the inhibition of LTP induction is completely attributable to effects on C-kinase, as previously suggested (Hvalby et al., 1994).

The cocktail of proteolysis inhibitors that we have used includes the calpain inhibitor leupeptin. When this cocktail was used without kinase inhibitor, robust LTP was observed. This finding is of interest because of previous work suggesting that LTP induction could be blocked by bath application of leupeptin (del Cerro et al., 1990; Denny et al., 1990). This led to the proposal that LTP induction required calpain activation in the postsynaptic cell. Our results do not support this proposal.

\section{Is a kinase involved in LTP maintenance?}

Although there is ambiguity about the concentration of inhibitor in the dendrites, it certainly produces the most powerful block of LTP induction yet achieved. This block is even more impressive if one considers the large magnitude of LTP in our experiments $(\sim 300 \%)$, as compared with that produced by a tetanus $(<200 \%)$. Therefore, it is clear that within 10-20 min after its intracellular introduction, the peptide reaches a highly effective concentration near its targets (Figs. 3, 5, 6). We thus have been able to answer a simple question: does similar application of the kinase inhibitor after LTP induction produce a block of maintenance? Such a block would be expected if the persistent kinase activity observed biochemically (Klann et al., 1991, 1992, 1993; Fukunaga et al., 1993, 1995; Sacktor et al., 1993; Ramakers et al., 1995; Hrabetova and Sacktor, 1996; Osten et al., 1996; Ouyang et al., 1996; Barria et al., 1997) were responsible for maintaining LTP via a postsynaptic process. Our results do not support this hypothesis. No decay in LTP level in comparison to control experiments was observed (Figs. 4, 7).

The simplest interpretation of these results is that postsynaptic kinase activity is important transiently during LTP induction but is not necessary for the maintenance of LTP. Perhaps maintenance is attributable to a postsynaptic kinase or kinases, which are not affected by our inhibitor, or attributable to a kinase or kinases that are not located in the postsynaptic cell (Malinow et al., 1989; Huang et al., 1992; Malgaroli et al., 1992). This interpretation is consistent with experiments in which bath-applied 

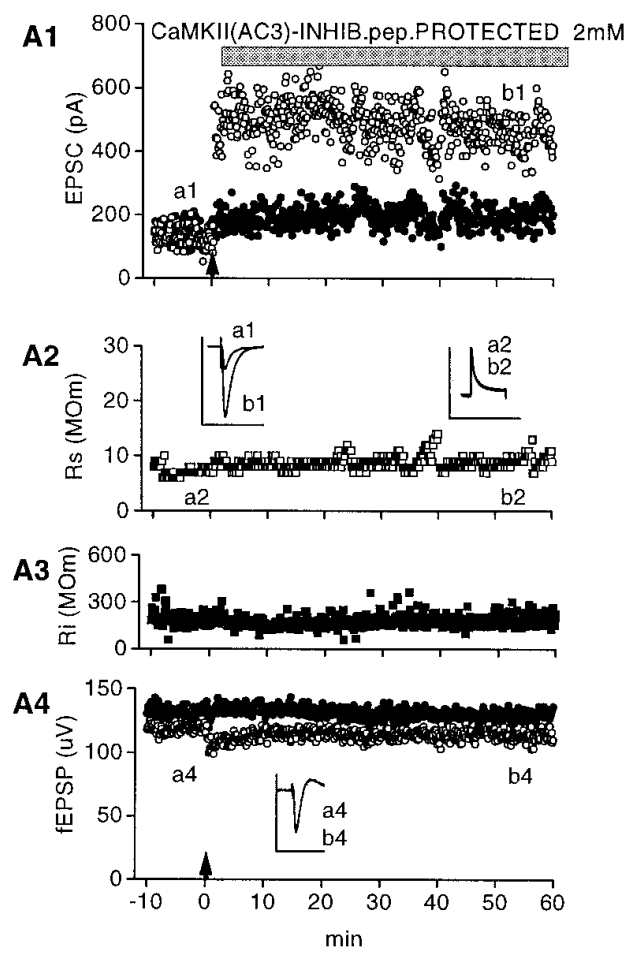
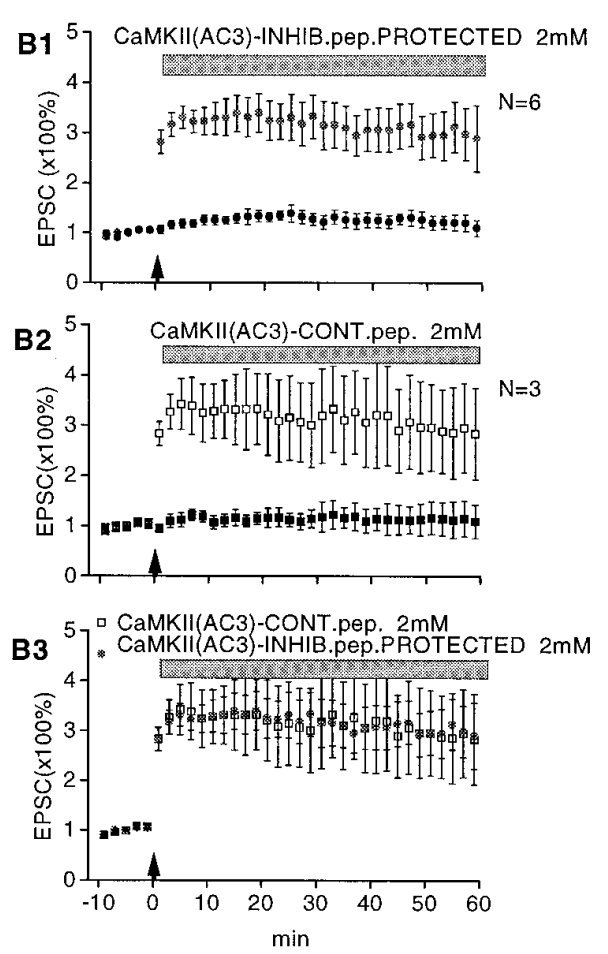

Figure 7. Intracellular application of the protected CaMKII(AC3) peptide inhibitor did not affect LTP maintenance. $A 1$, A representative experiment shows that no decline in the potentiated (open symbols) and control (filled symbols) synaptic responses is observed over time when the kinase inhibitor is added after LTP induction (arrow). Series resistance (A2), input resistance $(A 3)$, and extracellular field potentials $(A 4)$ were stable throughout the experiment. Insets in $A 2$, Left, Averages of 20 consecutive traces of EPSCs taken in the periods indicated in $A 1$; calibration, $600 \mathrm{pA}, 100 \mathrm{msec}$. Right, Averages of 20 consecutive traces of current transients used for monitoring series $(R s)$ and input resistance $(R i)$ during whole-cell recording, taken in the periods indicated in $A 2$; calibration, $300 \mathrm{pA}, 60 \mathrm{msec}$. Insets in $A 4$, Averages of 20 consecutive traces of extracellular recorded EPSPs ( $f E P S P)$, taken in the periods indicated in $A 4$; calibration, $200 \mu \mathrm{V}, 60 \mathrm{msec}$. $B$, Summary data for active kinase inhibitor $(B 1)$, control peptide (B2), and superposition of $B 1$ and B2 in B3. Gray or open symbols represent the pathway in which LTP was induced by pairing at the arrow. Filled symbols represent the control pathway. Protease inhibitors were included in all experiments. Horizontal bars indicate periods when inhibitors were applied. kinase inhibitors resulted in the decay of preestablished LTP (Lovinger et al., 1987; Malinow et al., 1988, 1989; Colley et al., 1990; Reymann et al., 1990; Matthies et al., 1991; Huber et al., 1995; Chen et al., 1996; Hrabetova and Sacktor, 1996). Recent work, however, shows that postsynaptic substrates of CaM-kinase and C-kinase are phosphorylated persistently for at least $1 \mathrm{hr}$ after LTP induction (Klann et al., 1992; Fukunaga et al., 1995; Ramakers et al., 1995). It is of interest, therefore, to consider how our results might be consistent with an important role for persistent postsynaptic kinase activity in LTP maintenance despite the fact that we observed no effect of kinase inhibitors on maintenance.

One possibility is based on the findings of Wang and Kelly (1996). They demonstrated that, when synaptic transmission is enhanced by LTP or postsynaptic biochemical manipulations, the resulting potentiation can be blocked by combined application of both CaM-kinase and $\mathrm{C}$-kinase inhibitors. It is conceivable that the constitutive CaM-kinase or C-kinase activity that occurs after LTP induction converges on a common target. Inhibition of both enzymes would be necessary for reversing LTP. Indeed there is very recent evidence (R. L. Huganir, personal communication; see also Roche et al., 1996) that GluR1 AMPA channel can be phosphorylated at the intracellular site by either CaM-kinase or C-kinase. However, the observation of Wang and Kelly (1996) was not confirmed in other experiments (Malinow et al., 1989; Huang et al., 1992; Malgaroli et al., 1992) that also combined intracellular introduction of the same peptide inhibitors or the nonspecific kinase inhibitor $\mathrm{H} 7$ (which inhibits several kinases, including $\mathrm{C}$-kinase and CaM-kinase).

Another possibility is that, for the effect of kinase inhibition to be observed, phosphatases must be active to reverse the kinase effect on its molecular target. For instance, if kinase expresses LTP by phosphorylating AMPA channels and thereby enhances the synaptic current, the effect of kinase inhibitor on maintenance would be observed only if there was sufficient resting phosphatase activity to dephosphorylate the channels and autoactivated kinase itself within the time course of our experiments. Perhaps resting phosphatase activity at potentiated synapses is low. Indeed, there is some indication that active CaM-kinase can lead to the inactivation of phosphatase 2A (Fukunaga et al., 1996). In cases in which kinase inhibitor did block LTP maintenance, microelectrodes were used (Wang and Feng, 1992; Feng, 1995; Wang and Kelly, 1996). Perhaps in those experiments the phosphatase activity may have been higher than under the conditions we studied.

The final possibility is that phosphorylated CaM-kinase plays an important role in the maintenance of LTP as a structural protein rather than as an enzyme. We know that during LTP induction CaM-kinase becomes autophosphorylated (Fukunaga et al., 1993, 1995; Ouyang et al., 1996; Barria et al., 1997), presumably because of $\mathrm{Ca}^{2+}$ elevation at active synapses. In particular, the kinase is autophosphorylated on Thr 286, a site that makes the kinase become persistently active even in the absence of $\mathrm{Ca}^{2+}$ (for review, see Hanson and Schulman, 1992). It is generally assumed that it is this activity that provides the important readout of the kinase. However, recent work has demonstrated that structural changes also depend on this site. McNeill and Colbran (1995) have found synaptic proteins that bind selectively to CaM-kinase phosphorylated on Thr 286. Hudmon et al. (1996) have shown that kinase polymerization reactions depend on autophosphorylation. These structural changes may lead to a complex that somehow enhances synaptic transmission but that is not affected readily by kinase inhibitors. Recent evidence (Strack et al., 1997) showing that when CaM-kinase becomes associated with the PSD it can no longer be dephosphorylated by phosphatase $2 \mathrm{~A}$ would be consistent with this view. 


\section{REFERENCES}

Andreasen M, Lambert JD (1995) Regenerative properties of pyramidal cell dendrites in area CA1 of the rat hippocampus. J Physiol (Lond) 483:421-441.

Barria A, Muller D, Griffith LC, Soderling TR (1997) Phosphorylation of AMPA-type glutamate receptors by $\mathrm{Ca}^{2+} /$ calmodulin-dependent protein kinase II during long-term potentiation. Science, in press.

Bliss TV, Collingridge GL (1993) A synaptic model of memory: longterm potentiation in the hippocampus. Nature 361:31-39.

Blitzer RD, Wong T, Nouranifar R, Iyengar R, Landau EM (1995) Postsynaptic cAMP pathway gates early LTP in hippocampal CA1 region. Neuron 15:1403-1414.

Bond JS, Butler PE (1987) Intracellular proteases. Annu Rev Biochem $56: 333-364$.

Braun AP, Schulman H (1995) A non-selective cation current activated via the multifunctional $\mathrm{Ca}^{2+} /$ calmodulin-dependent protein kinase in human epithelial cells. J Physiol (Lond) 488:37-55.

Cantor C, Schimmel PR (1980) Biophysical chemistry, Pt II, Techniques for the study of biological structure and function. San Francisco: Freeman.

Chen W, Wieraszko A, Hogan MV, Yang HA, Kornecki E, Ehrlich YH (1996) Surface protein phosphorylation by ecto-protein kinase is required for the maintenance of hippocampal long-term potentiation. Proc Natl Acad Sci USA 93:8688-8693.

Ciechanover A, Schwartz AL (1989) How are substrates recognized by the ubiquitin-mediated proteolytic system? Trends Biochem Sci 14:483-488.

Colley PA, Routtenberg A (1993) Long-term potentiation as synaptic dialogue. Brain Res Rev 18:115-122.

Colley PA, Sheu FS, Routtenberg A (1990) Inhibition of protein kinase C blocks two components of LTP persistence, leaving initial potentiation intact. J Neurosci 10:3353-3360.

del Cerro S, Larson J, Oliver MW, Lynch G (1990) Development of hippocampal long-term potentiation is reduced by recently introduced calpain inhibitors. Brain Res 530:91-95.

Denny JB, Polan-Curtain J, Ghuman A, Wayner MJ, Armstrong DL (1990) Calpain inhibitors block long-term potentiation. Brain Res 534:317-320.

Feng TP (1995) The involvement of PKC and multifunctional CaM kinase II of the postsynaptic neuron in induction and maintenance of long-term potentiation. Prog Brain Res 105:55-63.

Fernandez A, Mery J, Vandromme M, Basset M, Cavadore JC, Lamb NJ (1991) Effective intracellular inhibition of the cAMP-dependent protein kinase by microinjection of a modified form of the specific inhibitor peptide PKi in living fibroblasts. Exp Cell Res 195:468-477.

Fukunaga D, Muller D, Miyamoto E (1996) Role of protein phosphatases in hippocampal long-term potentiation. Soc Neurosci Abstr 22:331.

Fukunaga K, Stoppini L, Miyamoto E, Muller D (1993) Long-term potentiation is associated with an increased activity of $\mathrm{Ca}^{2+}$ calmodulin-dependent protein kinase II. J Biol Chem 268:7863-7867.

Fukunaga K, Muller D, Miyamoto E (1995) Increased phosphorylation of $\mathrm{Ca}^{2+} /$ calmodulin-dependent protein kinase II and its endogenous substrates in the induction of long-term potentiation. J Biol Chem 270:6119-6124.

GuptaRoy B, Griffith LC (1996) Functional heterogeneity of alternatively spliced isoforms of Drosophila $\mathrm{Ca}^{2+} /$ calmodulin-dependent protein kinase II. J Neurochem 66:1282-1288.

Hanse E, Gustafsson B (1994) Staurosporine impairs both short-term and long-term potentiation in the dentate gyrus in vitro. Neuroscience 58:263-274.

Hanson PI, Schulman H (1992) Neuronal $\mathrm{Ca}^{2+} /$ calmodulin-dependent protein kinases. Annu Rev Biochem 61:559-601.

Helmchen F, Imoto K, Sakmann B (1996) $\mathrm{Ca}^{2+}$ buffering and action potential-evoked $\mathrm{Ca}^{2+}$ signaling in dendrites of pyramidal neurons. Biophys J 70:1069-1081.

Hestrin S, Nicoll RA, Perkel DJ, Sah P (1990) Analysis of excitatory synaptic action in pyramidal cells using whole-cell recording from rat hippocampal slices. J Physiol (Lond) 422:203-225.

Hrabetova S, Sacktor TC (1996) Bidirectional regulation of protein kinase $\mathrm{M} \zeta$ in the maintenance of long-term potentiation and long-term depression. J Neurosci 16:5324-5333.

Hu GY, Hvalby O, Walaas SI, Albert KA, Skjeflo P, Andersen P, Greengard P (1987) Protein kinase C injection into hippocampal pyramidal cells elicits features of long-term potentiation. Nature 328:426-429.
Huang YY, Colley PA, Routtenberg A (1992) Postsynaptic then presynaptic protein kinase $\mathrm{C}$ activity may be necessary for long-term potentiation. Neuroscience 49:819-827.

Huber KM, Mauk MD, Kelly PT (1995) LTP induced by activation of voltage-dependent $\mathrm{Ca}^{2+}$ channels requires protein kinase activity. NeuroReport 6:1281-1284.

Hudmon A, Aronowski J, Kolb SJ, Waxham MN (1996) Inactivation and self-association of $\mathrm{Ca}^{2+} /$ calmodulin-dependent protein kinase II during autophosphorylation. J Biol Chem 271:8800-8808.

Hvalby O, Hemmings Jr HC, Paulsen O, Czernik AJ, Nairn AC, Godfraind JM, Jensen V, Raastad M, Storm JF, Andersen P, Greengard P (1994) Specificity of protein kinase inhibitor peptides and induction of long-term potentiation. Proc Natl Acad Sci USA 91:4761-4765.

Ishida A, Fujisawa H (1995) Stabilization of calmodulin-dependent protein kinase II through the autoinhibitory domain. J Biol Chem 270:2163-2170.

Jaffe DB, Johnston D, Lasser-Ross N, Lisman JE, Miyakawa H, Ross WN (1992) The spread of $\mathrm{Na}^{+}$spikes determines the pattern of dendritic $\mathrm{Ca}^{2+}$ entry into hippocampal neurons. Nature 357:244-246.

Klann E, Chen SJ, Sweatt JD (1991) Persistent protein kinase activation in the maintenance phase of long-term potentiation. J Biol Chem 266:24253-24256.

Klann E, Chen SJ, Sweatt JD (1992) Increased phosphorylation of a 17 $\mathrm{kDa}$ protein kinase C substrate (P17) in long-term potentiation. J Neurochem 58:1576-1579.

Klann E, Chen SJ, Sweatt JD (1993) Mechanism of protein kinase C activation during the induction and maintenance of long-term potentiation probed using a selective peptide substrate. Proc Natl Acad Sci USA 90:8337-8341.

Kullmann DM, Perkel DJ, Manabe T, Nicoll RA (1992) $\mathrm{Ca}^{2+}$ entry via postsynaptic voltage-sensitive $\mathrm{Ca}^{2+}$ channels can transiently potentiate excitatory synaptic transmission in the hippocampus. Neuron 9:1175-1183.

Lasser-Ross N, Miyakawa H, Lev-Ram V, Young SR, Ross WN (1991) High time resolution fluorescence imaging with a CCD camera. J Neurosci Methods 36:253-261.

Levitan IB (1994) Modulation of ion channels by protein phosphorylation and dephosphorylation. Annu Rev Physiol 56:193-212.

Lisman JE (1985) A mechanism for memory storage insensitive to molecular turnover: a bistable autophosphorylating kinase. Proc Natl Acad Sci USA 82:3055-3057.

Lisman JE, Goldring MA (1988) Feasibility of long-term storage of graded information by the $\mathrm{Ca}^{2+} /$ calmodulin-dependent protein kinase molecules of the postsynaptic density. Proc Natl Acad Sci USA 85:5320-5324.

Lisman J (1994) The CaM kinase II hypothesis for the storage of synaptic memory. Trends Neurosci 17:406-412.

Lledo PM, Hjelmstad GO, Mukherji S, Soderling TR, Malenka RC, Nicoll RA (1995) Calcium/calmodulin-dependent kinase II and longterm potentiation enhance synaptic transmission by the same mechanism. Proc Natl Acad Sci USA 92:11175-11179.

Lou LL, Lloyd SJ, Schulman H (1986) Activation of the multifunctional $\mathrm{Ca}^{2+} /$ calmodulin-dependent protein kinase by autophosphorylation: ATP modulates production of an autonomous enzyme. Proc Natl Acad Sci USA 83:9497-9501.

Lovinger DM, Wong KL, Murakami K, Routtenberg A (1987) Protein kinase $\mathrm{C}$ inhibitors eliminate hippocampal long-term potentiation. Brain Res 436:177-183.

Magee JC, Johnston D (1997) A synaptically controlled, associative signal for Hebbian plasticity in hippocampal neurons. Science 275:209-213.

Malenka RC, Nicoll RA (1993) NMDA receptor-dependent synaptic plasticity: multiple forms and mechanisms. Trends Neurosci 16:521-527.

Malenka RC, Kauer JA, Perkel DJ, Mauk MD, Kelly PT, Nicoll RA, Waxham MN (1989) An essential role for postsynaptic calmodulin and protein kinase activity in long-term potentiation. Nature 340:554-557.

Malgaroli A, Malinow K, Schulman H, Tsien RW (1992) Persistent signaling and changes in presynaptic function in long-term potentiation. In: Interactions among cell signaling systems (Sato R, ed), pp 176-191. Chichester, UK: Wiley.

Malinow R, Tsien RW (1990) Presynaptic enhancement shown by whole-cell recordings of long-term potentiation in hippocampal slices. Nature 346:177-180. 
Malinow R, Madison DV, Tsien RW (1988) Persistent protein kinase activity underlying long-term potentiation. Nature 335:820-824.

Malinow R, Schulman H, Tsien RW (1989) Inhibition of postsynaptic PKC or CaMKII blocks induction but not expression of LTP. Science 245:862-866.

Malinow R, Otmakhov N, Blum KI, Lisman J (1994) Visualizing hippocampal synaptic function by optical detection of $\mathrm{Ca}^{2+}$ entry through the $N$-methyl-D-aspartate channel. Proc Natl Acad Sci USA 91:8170-8174.

Matthies Jr H, Behnisch T, Kase H, Matthies H, Reymann KG (1991) Differential effects of protein kinase inhibitors on pre-established longterm potentiation in rat hippocampal neurons in vitro. Neurosci Lett 121:259-262.

Mayer ML, Westbrook GL, Guthrie PB (1984) Voltage-dependent block by $\mathrm{Mg}^{2+}$ of NMDA responses in spinal cord neurons. Nature 309:261-263.

McGlade-McCulloh E, Yamamoto H, Tan SE, Brickey DA, Soderling TR (1993) Phosphorylation and regulation of glutamate receptors by calcium/calmodulin-dependent protein kinase II. Nature 362:640-642.

McNeill RB, Colbran RJ (1995) Interaction of autophosphorylated $\mathrm{Ca}^{2+} /$ calmodulin-dependent protein kinase II with neuronal cytoskeletal proteins. Characterization of binding to a $190 \mathrm{kDa}$ postsynaptic density protein. J Biol Chem 270:10043-10049.

Miller SG, Kennedy MB (1986) Regulation of brain type II $\mathrm{Ca}^{2+} /$ calmodulin-dependent protein kinase by autophosphorylation: $\mathrm{a} \mathrm{Ca}^{2+}$. triggered molecular switch. Cell 44:861-870.

Nowak L, Bregestovski P, Ascher P, Herbet A, Prochiantz A (1984) Magnesium gates glutamate-activated channels in mouse central neurones. Nature 307:462-465.

Ocorr KA, Schulman H (1991) Activation of multifunctional $\mathrm{Ca}^{2+} /$ calmodulin-dependent kinase in intact hippocampal slices. Neuron 6:907-914.

O'Dell TJ, Kandel ER, Grant SG (1991) Long-term potentiation in the hippocampus is blocked by tyrosine kinase inhibitors. Nature 353:558-560.

Osten P, Valsamis L, Harris A, Sacktor TC (1996) Protein synthesisdependent formation of protein kinase $\mathrm{M} \zeta$ in long-term potentiation. J Neurosci 16:2444-2451.

Otmakhov N, Lisman JE (1995) Intracellular perfusion of phosphatase inhibitor reversibly potentiates synaptic transmission and blocks IAHP in hippocampal CA1 pyramidal neurons. Soc Neurosci Abstr 21:262.

Ouyang Y, Schuman EM, Harris K, Kennedy MB (1996) Effect of tetanus on the distribution of autophosphorylated CaM kinase II in the CA1 region of rat hippocampus. Soc Neurosci Abstr 22:1510.
Pusch M, Neher E (1988) Rates of diffusional exchange between small cells and a measuring patch pipette. Pflügers Arch 411:204-211.

Ramakers GM, De Graan PN, Urban IJ, Kraay D, Tang T, Pasinelli P, Oestreicher AB, Gispen WH (1995) Temporal differences in the phosphorylation state of pre- and postsynaptic protein kinase $\mathrm{C}$ substrates B-50/GAP-43 and neurogranin during long-term potentiation. J Biol Chem 270:13892-13898.

Rexhausen U (1992) Determination of diffusion properties of fluorescent dyes in dendritic trees of nerve cells by using a computerized imaging system. PhD thesis, Max-Planck-Institut of Biophysical Chemistry, p 91.

Reymann KG, Davies SN, Matthies H, Kase H, Collingridge GL (1990) Activation of K-252b-sensitive protein kinase is necessary for a postsynaptic phase of long-term potentiation in area CA1 of rat hippocampus. Eur J Neurosci 2:481-486.

Roberson ED, English JD, Sweatt JD (1996) A biochemist's view of long-term potentiation. Learn Memory 3:1-24.

Roche KW, O’Brien RJ, Mammen AL, Bernhardt J, Huganir RL (1996) Characterization of multiple phosphorylation sites on the AMPA receptor GluR1 subunit. Neuron 16:1179-1188.

Sacktor TC, Osten P, Valsamis H, Jiang X, Naik MU, Sublette E (1993) Persistent activation of the zeta isoform of protein kinase $\mathrm{C}$ in the maintenance of long-term potentiation. Proc Natl Acad Sci USA 90:8342-8346.

Strack S, Barban MA, Wadzinski BE, Colbran R (1997) Differential inactivation of postsynaptic density-associated and soluble $\mathrm{Ca}^{2+}$ calmodulin-dependent protein kinase II by protein phosphatases type I and 2A. J Neurochem 68:2119-2128.

Stuart GJ, Sakmann B (1994) Active propagation of somatic action potentials into neocortical pyramidal cell dendrites. Nature 367:69-72.

Stuart GJ, Sakmann B (1995) Amplification of EPSPs by axosomatic sodium channels in neocortical pyramidal neurons. Neuron 15:1065-1076.

Suzuki T (1994) Protein kinases involved in the expression of long-term potentiation. Int J Biochem 26:735-744.

Wang JH, Feng DP (1992) Postsynaptic protein kinase C essential to induction and maintenance of long-term potentiation in the hippocampal CA1 region. Proc Natl Acad Sci USA 89:2576-2580.

Wang JH, Kelly PT (1995) Postsynaptic injection of $\mathrm{Ca}^{2+} / \mathrm{CaM}$ induces synaptic potentiation requiring CaMKII and PKC activity. Neuron $15: 443-452$.

Wang JH, Kelly PT (1996) The balance between postsynaptic $\mathrm{Ca}^{2+}$ dependent protein kinase and phosphatase activities controlling synaptic strength. Learn Memory 3:170-181. 